\title{
Population Characteristics of Ozark Bass (Ambloplites constellatus) in the Upper White River Basin of Northern Arkansas
}

\author{
Ashley Rodman1, Kristofor R. Brye ${ }^{2}$, Daniel Magoulick ${ }^{3}$, Stan Todd4 \\ ${ }^{1}$ Buffalo National River, National Park Service, Harrison, AR, USA \\ ${ }^{2}$ Department of Crop, Soil, and Environmental Sciences, University of Arkansas, Fayetteville, USA \\ ${ }^{3}$ U.S. Geological Survey, Arkansas Cooperative Fish and Wildlife Research Unit, Department of Biological Sciences, \\ University of Arkansas, Fayetteville, USA \\ ${ }^{4}$ Arkansas Game and Fish Commission, Little Rock, AR, USA \\ Email: ashley_rodman@nps.gov, kbrye@uark.edu,danmag@uark.edu, Charles.Todd@agfc.ar.gov
}

How to cite this paper: Rodman, A., Brye, K.R., Magoulick, D. and Todd, S. (2019) Population Characteristics of Ozark Bass (Ambloplites constellatus) in the Upper White River Basin of Northern Arkansas. Natural Resources, 10, 121-138.

https://doi.org/10.4236/nr.2019.105009

Received: March 24, 2019

Accepted: May 5, 2019

Published: May 8, 2019

Copyright $\odot 2019$ by author(s) and Scientific Research Publishing Inc. This work is licensed under the Creative Commons Attribution International License (CC BY 4.0).

http://creativecommons.org/licenses/by/4.0/

\begin{abstract}
Ozark Bass (Ambloplites constellatus) is an understudied, endemic fish species in the Upper White River Basin of northern Arkansas. This study was part of an effort by fisheries managers to gather baseline data about the Ozark Bass to aid in understanding population dynamics and contribute to the limited data available for use in determining the efficacy of harvest regulations. Select population characteristics of Ozark Bass in two northern Arkansas streams were determined, population characteristics of Ozark Bass were compared to Shadow Bass (Ambloplites ariommus) and Rock Bass (Ambloplites rupestris) data collected from previous studies in southern Missouri, and relative condition, length-at-age, and annual survival of Ozark Bass were compared between sample streams. Sampling occurred in Crooked Creek and the Buffalo River during summer 2013 via boat electroshocking. Length and weight data were recorded for all Ozark Bass collected, and fish ages were determined through selective otolith retrieval and age-length keys. Ozark Bass in Crooked Creek had greater relative condition than Ozark Bass in Buffalo River $(P<0.001)$. Neither Ozark bass lengths nor log-transformed weights differed $(P>0.05)$ between sexes for fish collected from only the Buffalo River. Ozark Bass mean annual survival was similar between Crooked Creek $(55 \% \pm 5 \%$ as $95 \%$ confidence interval (CI)) and the Buffalo River $(50 \% \pm 7 \%$ CI) for fish age 2 to 9. Calculated Ozark Bass lengths-at-age for fish from both streams were comparable to the Von Bertalanffy growth estimates, except the Buffalo River age 7 category where there was only one observation. The relationship between Ozark Bass age and length differed between sam-
\end{abstract}


pled streams, and variability in growth rates and length-at-age were observed among Ambloplites species. Results of this study contribute to the understanding of the population dynamics of the Ozark Bass that will lead to improved fisheries management.

\section{Keywords}

Endemic, Fish Measurements, Fishing Regulations, Ozarks

\section{Introduction}

The Ozark bass (Ambloplites constellatus) is a sport fish endemic to the Upper White River Basin of southern Missouri and northern Arkansas [1]. Until 1977, Ozark bass, shadow bass (Ambloplites ariommus), and rock bass (Ambloplites rupestris) were collectively recognized as Ambloplites rupestris [2]. Although closely related to Ozark bass, shadow bass and rock bass are more widely distributed throughout the mid-western United States, in addition to being present in the White River Basin [1]. Even though angler harvest is common, Ozark bass growth and other population characteristics have been minimally studied. However, even small changes in Ozark bass population characteristics could have potentially major implications for the species as a whole due to their narrow geographic range. Consequently, knowledge of Ozark bass' population characteristics and life cycle is necessary for fisheries biologists and managers to make informed management decisions, such as maximum harvest regulations, and for predicting possible changes to population dynamics throughout the known habitat range of Ozark bass.

The Upper White River Basin in northern Arkansas and southern Missouri, which encompasses most of the known range of Ozark bass, is a unique geographic setting due to the prevalence of underlying karst geology. However, the karst geology poses potential surface water and groundwater quality concerns due to ease of contamination because of the inter-connectedness of surface water and groundwater in regions of karst geology. Consequently, altered water quality, as a result of land-use change within the habitat range and/or changes to watershed hydrology, may be a threat to Ozark bass [3] [4], especially considering that little is known about the Ozark bass' growth habits and population dynamics.

In addition to potentially shifting water quality, human activities and potential climate change may affect the sustainability of the Ozark bass population. Human activities threaten Crooked Creek and Buffalo River, two important tributaries of the White River where Ozark bass are known to inhabit. Gravel mining caused Crooked Creek to be included on the 2016 Arkansas Department of Environmental Quality's 303(d) list of impaired waterbodies due to elevated total dissolved solids [5] [6]. Annual recreational visitation to the Buffalo River increased by over $800 \%$ since the early 1970 s, from around 200,000 visitors in 1974 
to over 1.7 million visitors in 2016 [7], where increased visitation has also increased angling pressure. Consequently, the Arkansas Game and Fish Commission (AGFC) recently enforced stricter harvest limitations on smallmouth bass (Micropterus dolomieu) [8]. However, it is unknown if more Ozark bass will be harvested in response to the new smallmouth bass regulations.

Climate change models for the southeastern United States predict an increase in the number and duration of droughts, greater mean annual air temperature, as well as an increased frequency of heavy rain events with shorter durations in the future [9]. The impacts of a potentially changing climate on Ozark bass populations are unknown at this time, but studies have suggested other sport fish may expand their habitat range and exhibit changes in growth rate potential [10].

Population data aid fisheries biologists and managers in evaluating current regulations to ensure that overfishing does not occur and also guide the modification of population size structure. Due to the lack of historical information, describing and evaluating the present population characteristics of the Ozark bass are critical for assessment of current and potential future impacts, such as altered water quality, climate change, and/or angling pressure, to the Ozark bass population. Any information generated for an under-studied aquatic species, such as the Ozark bass, will improve aquatic ecosystem management and protect certain species from over-exploitation. Due to the relatively recent taxonomic split of the Ozark bass from other similar species, further research is warranted. Therefore, the objectives of this study were to: 1) determine population characteristics (i.e., relative condition, length-at-age, and annual survival) for Ozark bass in northern Arkansas; 2) compare relative condition, length-at-age, and annual survival of Ozark bass between sampled streams; and 3) compare Ozark bass population characteristics to those of other more well-studied bass species (i.e., shadow bass and rock bass) within the region. It was hypothesized that: 1) Ozark bass from the Buffalo River would have similar lengths-at-age and relative condition and lower annual survival than those from Crooked Creek because of greater fishing pressure in the Buffalo River [7] [11]; and 2) there would be similarities in population characteristics among sampled Ozark bass and other Ambloplites species due to similar phylogenetic histories.

\section{Materials and Methods}

\subsection{Site Description}

The Upper White River Basin, located in northern Arkansas and southern Missouri is collectively composed of portions of the Ozark Highlands to the north and the Boston Mountains to the south. The Boston Mountains are primarily sandstone, shale, and siltstone, while the Ozark Highlands are characterized by limestone, dolomite, chert, and sandstone [12]. The Buffalo River drains 3471 $\mathrm{km}^{2}$ of the Boston Mountains and Ozark Highlands ecoregions and Crooked Creek drains $1197 \mathrm{~km}^{2}$ of the Ozark Highlands ecoregion [13] [14] [15]. Mean 
air temperatures have historically (1981 to 2010 ) ranged from $18.7^{\circ} \mathrm{C}$ to $30.8^{\circ} \mathrm{C}$ during the summer months and mean annual precipitation is $112.1 \mathrm{~cm}$ within the region [16]. Ozark bass are generally present near large rocks in stream pools that have a large dissolved oxygen concentration, perennial flow, and low turbidity [1] [17]. The Buffalo River and Crooked Creek are typical streams for the Ozark Highlands and Boston Mountains ecoregions, with riffle-pool morphology and diverse and abundant fish, including smallmouth bass, long ear sunfish (Lepomis megalotis), and multiple darter and minnow species, among others [18] [19].

\subsection{Data Collection}

An electrofishing boat with pulsed direct current was used to collect Ozark bass from three locations within the Lower Wilderness Area (LWA) of the Buffalo River on June 10,11, and 12, 2013, and from two locations on Crooked Creek on June 21 and 24, 2013 (Figure 1). Sampling sites were selected on Crooked Creek based on accessibility, nearby access availability, and ample space for the electrofishing boat to properly maneuver. Sampling sites on the Buffalo River were distributed across the LWA, which was not previously sampled during the only known Ozark bass-specific study conducted on the Buffalo River [17]. Summer was chosen for the study season because water levels are generally low and fish are more concentrated, active, and easily caught. Buffalo River sampling occurred at night to avoid disturbing park visitors, while Crooked Creek sampling occurred during the day. During June 2013, mean stream flow was $40.4 \mathrm{~m}^{3} \cdot \mathrm{s}^{-1}$ for the Buffalo River near Harriet, AR, which was $\sim 32 \mathrm{~km}$ upstream of the

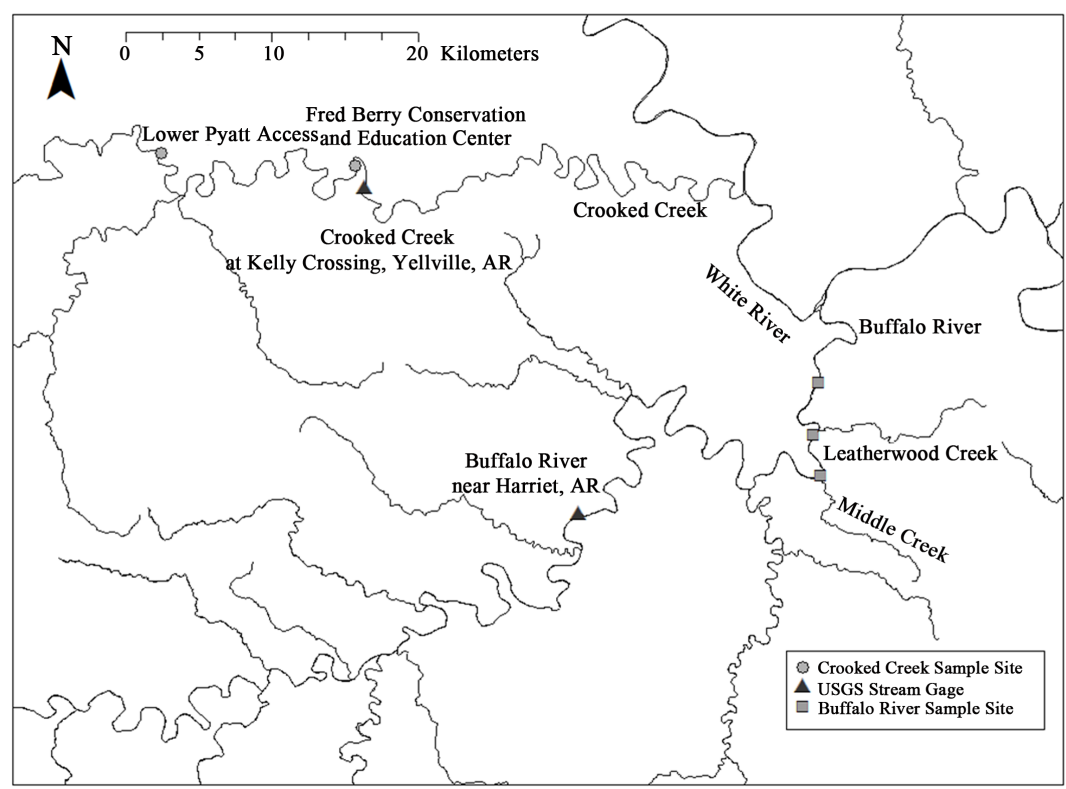

Figure 1. Distribution of sampling sites along the Buffalo River and Crooked Creek in north-central Arkansas. Circles represent sites sampled on Crooked Creek. Squares represent sites sampled on the Buffalo River. Triangles represent U.S. Geological Survey (USGS) stream gaging stations. 
closest sampling site on the Buffalo River, compared to $3.3 \mathrm{~m}^{3} \cdot \mathrm{s}^{-1}$ for Crooked Creek at Kelly Crossing near Yellville, AR, which was $\sim 3 \mathrm{~km}$ downstream of the closest sampling site on Crooked Creek (Figure 1) [20]. A total of 16, timed, electrofishing runs were conducted in the LWA of the Buffalo River: six near Middle Creek, five above Leatherwood Creek, and five below Leatherwood Creek (Table 1; Figure 1). In Crooked Creek, five timed runs were conducted at both the AGFC Fred Berry Conservation and Education Center (FBCEC) located near Yellville and at the AGFC Lower Pyatt Access (Table 1; Figure 1).

Ozark bass were sampled in pools and other deep habitats reachable by boat. Each run lasted approximately 10 minutes. The weight, to the nearest \pm 2 grams, and the total length, to the nearest millimeter, of each fish collected were recorded. The first 10 fish consecutively collected at each site in each $10-\mathrm{mm}$ size class, if available, were retained and stored on ice in a cooler for sagittal otolith retrieval. When the maximum of 10 fish in any given size class had been collected, all additional fish collected in the same size class thereafter were weighed, measured, and released. Sex was only recorded from a sub-sample of Ozark bass from the Buffalo River to compare length and weight because differences were not observed between sexes.

Sagittal otoliths were sectioned with a low-speed saw, glued to glass slides, and then sanded and polished. Annuli were counted under a microscope by two observers to determine the age of the sampled fish. Both observers independently recounted the annuli and compared results to achieve a consensus when records indicated observational differences.

Since little historic population characteristic data exist for Ozark bass, similar data were gathered for the better-studied shadow and rock bass in the region for comparison. Shadow bass data from the Spring River and Eleven Point River in Arkansas were gathered from previously published literature and age data were derived from fish otoliths collected from 2003 through 2007 (Brett Timmons, AGFC, pers. comm.) [21]. Unpublished rock bass data from the Osage Fork of the Gasconade River in Missouri were provided by the Missouri Department of Conservation (MDC) and age data were derived from fish scales collected in 2011 (Craig Fuller, MDC, pers. comm.).

Table 1. Coordinates for Ozark bass (Ambloplites constellatus) sampling sites in two northern Arkansas streams within the Upper White River Basin.

\begin{tabular}{cccc}
\hline Waterbody & Sampling Site & Longitude & Latitude \\
\hline Crooked Creek & FBCEC $^{*}$ & $92^{\circ} 42^{\prime} 52.6^{\prime \prime} \mathrm{W}$ & $36^{\circ} 14^{\prime} 23.3^{\prime \prime} \mathrm{N}$ \\
& Lower Pyatt Access & $92^{\circ} 50^{\prime} 04.6^{\prime \prime} \mathrm{W}$ & $36^{\circ} 14^{\prime} 47.4^{\prime \prime} \mathrm{N}$ \\
Buffalo River & Middle Creek & $92^{\circ} 25^{\prime} 44.4^{\prime \prime} \mathrm{W}$ & $36^{\circ} 05^{\prime} 11.4^{\prime \prime} \mathrm{N}$ \\
& Downstream Leatherwood Creek & $92^{\circ} 25^{\prime} 48.4^{\prime \prime} \mathrm{W}$ & $36^{\circ} 07^{\prime} 58.8^{\prime \prime} \mathrm{N}$ \\
& Upstream Leatherwood Creek & $92^{\circ} 25^{\prime} 48.7^{\prime \prime} \mathrm{W}$ & $36^{\circ} 06^{\prime} 33.5^{\prime \prime} \mathrm{N}$ \\
\hline
\end{tabular}

${ }^{\star}$ Fred Berry Conservation and Education Center (FBCEC). 


\subsection{Calculations and Data Analyses}

Relative condition was calculated for Ozark bass from both the Buffalo River and Crooked Creek according to Le Cren [22]:

$$
K n=\left(W / W^{\prime}\right) * 100
$$

where $K n$ is relative condition, $W$ is weight of the individual fish, and $W^{\prime}$ is a length-specific weight derived from the regression equation of $\log 10$ transformed weight-length data for historic Ozark bass data $(n=7188)$ from the Upper White River Basin (Table 2).

The population age distributions were estimated for both streams using population length frequencies and age-length keys generated from fish with known lengths and ages determined from sagittal otolith observations [23]. Annual survival rates were calculated for 2- to 9-year-old Ozark bass using the population age distributions from Crooked Creek and the Buffalo River [24]. Based on prior experience and visual observation during sampling, fish younger than age 2 were not fully recruited to the sampling gear, thus these data were not included in the calculations. Von Bertalanffy equations were developed separately for the Buffalo River and Crooked Creek and used to develop length-at-age models for Ozark bass from all available age groups to compare to observed length-at-age data [25], where ages were based on age length keys. Catch per effort (CPE) was calculated for each sampling site and averaged by stream.

Data were assessed graphically using histograms, box plots, bar plots, and scatter plots to visually examine data distributions, variances, and potential outliers to ensure the assumptions of parametric tests used were met. Data were transformed, if non-normally distributed, to better meet the normality assumption of parametric tests. Independence assumptions were checked using the Durbin-Watson statistic for all analysis of variance (ANOVA) tests. The Brown

Table 2. Summary of locations of Ozark bass weight-length data ( $\mathrm{n}=7188$ total), collected by the Arkansas Game and Fish Commission between 1986 and 2013, that were used to develop the regression equation to determine the length-specific weight variable used in Equation (1).

\begin{tabular}{ccc}
\hline Site & Longitude & Latitude \\
\hline Buffalo River within the Lower Wilderness Area & $92^{\circ} 25^{\prime} 48.98^{\prime \prime} \mathrm{W}$ & $36^{\circ} 8^{\prime} 19.96^{\prime \prime} \mathrm{N}$ \\
Crooked Creek near Yellville, AR & $92^{\circ} 50^{\prime} 6.21^{\prime \prime} \mathrm{W}$ & $36^{\circ} 14^{\prime} 47.73^{\prime \prime} \mathrm{N}$ \\
Kings River & $93^{\circ} 35^{\prime} 38.71^{\prime \prime} \mathrm{W}$ & $36^{\circ} 8^{\prime} 36.05^{\prime \prime} \mathrm{N}$ \\
Long Creek near Alpena, AR & $93^{\circ} 16^{\prime} 54.78^{\prime \prime} \mathrm{W}$ & $36^{\circ} 17^{\prime} 30.36^{\prime \prime} \mathrm{N}$ \\
North Sylamore Creek near Fifty-Six, AR & $92^{\circ} 15^{\prime} 0.80^{\prime \prime} \mathrm{W}$ & $36^{\circ} 1^{\prime} 7.07^{\prime \prime} \mathrm{N}$ \\
Osage Creek near Alpena, AR & $93^{\circ} 24^{\prime} 57.01 " \mathrm{~W}$ & $36^{\circ} 11^{\prime} 25.39^{\prime \prime} \mathrm{N}$ \\
Piney Creek near Violet Hill, AR & $91^{\circ} 48^{\prime} 28.00^{\prime \prime} \mathrm{W}$ & $36^{\circ} 7^{\prime} 8.00^{\prime \prime} \mathrm{N}$ \\
Roasting Ear Creek near Fifty-Six, AR & $92^{\circ} 12^{\prime} 56.00^{\prime \prime} \mathrm{W}$ & $35^{\circ} 54^{\prime} 34.00^{\prime \prime} \mathrm{N}$ \\
Strawberry River & $91^{\circ} 47^{\prime} 60.00^{\prime \prime} \mathrm{W}$ & $36^{\circ} 13^{\prime} 32.00^{\prime \prime} \mathrm{N}$ \\
War Eagle Creek & $93^{\circ} 41^{\prime} 36.51^{\prime \prime} \mathrm{W}$ & $36^{\circ} 7^{\prime} 14.49^{\prime \prime} \mathrm{N}$ \\
\hline
\end{tabular}


Forsythe test was used to assess homogeneity of variance for residuals when analyzing data using one-way ANOVA. A two-factor ANOVA was conducted separately by stream to evaluate the effects of age class, sampling sites, and their interaction on Ozark bass mean length. One-factor ANOVAs were used to examine the effects of sex on Buffalo River Ozark bass length and weight. Data from both sexes were combined for calculating and comparing other population characteristics when significant differences were not observed $(P>0.05)$. Relative condition was compared between streams using a Welch two-sample t-test. A two-factor ANOVA was used to examine the effects of stream and fish species (Ozark bass, shadow bass, and rock bass) on fish length-at-age. Following Robson and Chapman [24], 95\% confidence intervals (CI) were used to compare Ozark bass annual survival between streams. Significance was judged at $P<0.05$ for all statistical tests and all statistical analyses were conducted using R Statistical Software [26]. Calculated length-at-age for each stream and Von Bertalanffy estimated length-at-age data were compared visually through graphical analysis.

\section{Results}

\subsection{Population Structure and Catch per Effort}

A total of 139 Ozark bass were collected from the LWA of the Buffalo River in approximately 4.3 hours (57 near Middle Creek, 45 above Leatherwood Creek, and 37 below Leatherwood Creek). A total of 188 Ozark bass were collected from Crooked Creek in approximately 1.8 hours ( 86 at the FBCEC and 102 at the Lower Pyatt Access). Mean CPE for Ozark bass in Buffalo River and Crooked Creek was 32.9 fish/hour $( \pm 4.5$ for the $95 \%$ CI) and 101.5 fish/hour $( \pm 29.6$ for the $95 \% \mathrm{CI}$ ), respectively. Sagittal otoliths were retrieved and aged from 117 Ozark bass from Buffalo River and 127 Ozark bass from Crooked Creek. Mean total lengths $(\mathrm{mm})$ of all recorded Ozark bass from Buffalo River and Crooked Creek were $151.2 \mathrm{~mm}[ \pm 4.0$ standard error (SE)] and $161.7 \mathrm{~mm}( \pm 2.9 \mathrm{SE})$, respectively. Fish collected from the Buffalo River ranged from 61 to $256 \mathrm{~mm}$ in total length and there was a noticeable decline in the number of fish collected over $220 \mathrm{~mm}$ in the Buffalo River, with no fish collected in the $240-\mathrm{mm}$ size class. Fish collected from Crooked Creek ranged from 88 to $260 \mathrm{~mm}$ in total length, with a noticeable decline in the number of fish collected above the 210-mm size class. Though not formally compared, the age distribution among fish collected was somewhat similar between the Buffalo River and Crooked Creek (Figure 2), with the majority of the collected fish from both water bodies being 5 years old or younger.

\subsection{Ozark Bass Length and Weight Comparisons between Sexes}

Neither Ozark bass lengths nor log-transformed weights differed $(P>0.05)$ between sexes for fish collected from only the Buffalo River (female mean length = $165 \mathrm{~mm}$, mean weight $=104 \mathrm{~g}$, and $\mathrm{n}=46$; male mean length $=169 \mathrm{~mm}$, mean weight $=110 \mathrm{~g}$, and $\mathrm{n}=50$ ). Consequently, fish-size data were combined across 


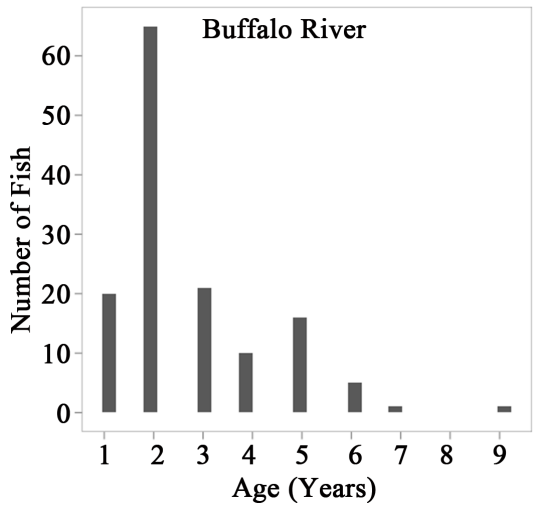

(a)

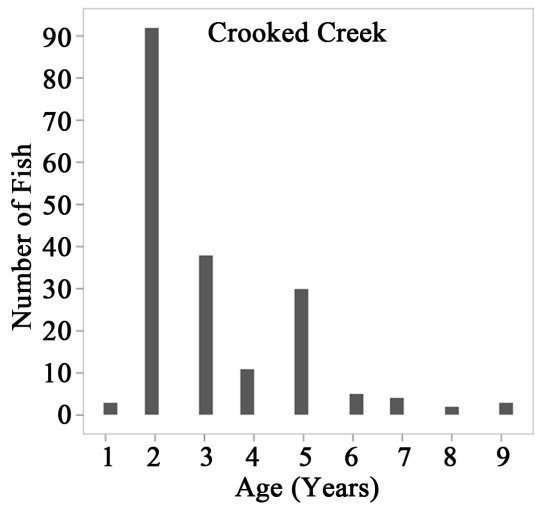

(b)

Figure 2. Numbers of Ozark bass collected in each represented age class from the a) Buffalo River and b) Crooked Creek, Arkansas from summer 2013.

sexes for calculation of age, relative condition, length-at-age, and annual survival for both streams.

\subsection{Relative Condition and Annual Survival Comparisons between Streams}

Mean relative condition of Ozark bass was greater in Crooked Creek than in the Buffalo River $(P<0.001$; Figure 3$)$. Relative condition of Ozark bass from the Buffalo River ranged from $75.6 \%$ to $153 \%$ and averaged $95.9 \%$, while relative condition of Ozark bass from Crooked Creek ranged from $83.1 \%$ to $123 \%$ and averaged $104 \%$ (Figure 3).

Neither sampling site nor the interaction of age and sampling site influenced mean length of Ozark bass in Crooked Creek or the Buffalo River $(P>0.05$; Table 3), thus annual survival was not calculated for individual sampling sites. However, mean annual survival rates of Ozark bass, age 2 to 9, were similar across streams and averaged $50 \%( \pm 7 \%$ for the $95 \%$ CI) and $55 \%( \pm 5 \%$ for the 95\% CI) for the Buffalo River and Crooked Creek, respectively.

\subsection{Length-at-Age Comparison between Streams and Von Bertalanffy Estimates}

The length-at-age data for both sampled streams depicted similar trends, where length generally increased as the fish aged (Figure 4). However, the relationship between age and length differed somewhat across streams $(P<0.001$; Table 4$)$ Ozark bass from Buffalo river were shorter compared to those from Crooked Creek at age 1, but length-at-age was greater in the Buffalo River compared to in Crooked Creek from age 2 to age 6 (Figure 4). Length-at-age between streams after age 6 was unable to be compared because data were either unavailable (e.g., no age 8 fish were collected from the Buffalo River) or there was only one fish collected (e.g., $\mathrm{n}=1$ for both age 7 and age 9 fish collected in the Buffalo River). Growth was greater in the Buffalo River up to age 3 and became more similar between 


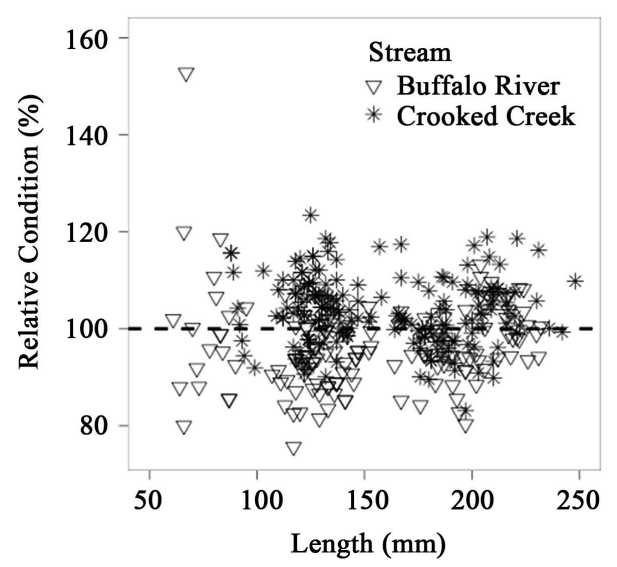

Figure 3. Scatter plot of relative condition versus length $(\mathrm{mm})$ of Ozark bass collected from Buffalo River (triangles) and Crooked Creek (asterisks). Dashed horizontal line represents mean relative condition for Ozark bass from the Upper White River Basin. Any values above the dashed horizontal line suggest fish were in better condition than the average Ozark bass in the Upper White River Basin, while values below the dashed horizontal line suggest fish were less well conditioned than average Ozark bass in the Upper White River Basin.

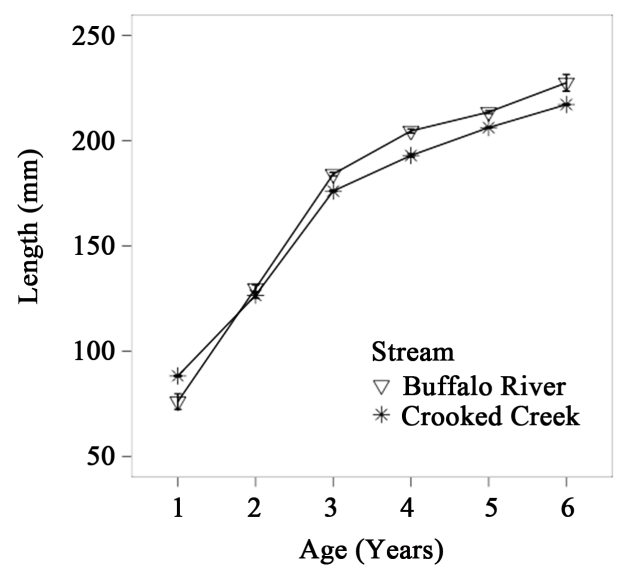

Figure 4. Ozark bass length-at-age means for the Buffalo River (triangles) and Crooked Creek (asterisks). Error bars are standard error. Lengths-at-age between streams after age 6 were unable to be compared because data were either unavailable (e.g., no age 8 fish were collected from the Buffalo River) or there was only one fish collected (e.g., $n=1$ for both age 7 and age 9 fish collected in the Buffalo River).

Table 3. Analysis of variance summary of the effects age, sampling site, and their interaction on the length of Ozark bass collected separately from Crooked Creek (i.e., Pyatt and Fred Berry Conservation and Education Center, AR) and Buffalo River (i.e., Middle Creek, above Leatherwood Creek, and below Leatherwood Creek, AR) sampling sites.

\begin{tabular}{ccc}
\hline \multirow{2}{*}{ Source of Variation } & Crooked Creek & Buffalo River \\
\cline { 2 - 3 } & & $P$ \\
\hline Age & $<0.001$ & $<0.001$ \\
Site & 0.379 & 0.378 \\
Age x site & 0.994 & 0.310 \\
\hline
\end{tabular}


Table 4. Analysis of variance summary of the effects age, stream, and their interaction on the length of Ozark bass collected separately from Crooked Creek and Buffalo River, AR.

\begin{tabular}{cccccc}
\hline Source of Variation & $P$ & Degrees of Freedom & Sum of Squares & Mean Square & F Ratio \\
\hline Age & $<0.001$ & 5 & 75809 & 15162 & 1286.4 \\
Stream & $<0.002$ & 1 & 164 & 164 & 13.9 \\
Age x stream & $<0.001$ & 5 & 462 & 92 & 7.8 \\
\hline
\end{tabular}

streams after age 3, but overall growth was greatest in the Buffalo River (Figure 4). The greatest growth rates for both streams were observed up to age 3 , after which growth rates declined in both streams (Figure 4).

Von Bertalanffy terms for the Buffalo River were $258 \mathrm{~mm}$ for maximum attainable length $\left(L_{\infty}\right), 0.346$ for the growth constant $(k)$, and -0.087 for the length-at-age $0\left(t_{\mathrm{o}}\right)$. The terms for Crooked Creek were $260 \mathrm{~mm}$ for maximum attainable length $\left(\mathrm{L}_{\infty}\right), 0.299$ for the growth constant $(k)$, and -0.328 for the length-at-age $0\left(t_{0}\right)$. Length-at-age for both Crooked Creek and Buffalo River followed similar trends to the estimated Von Bertalanffy growth curves; however, Buffalo River Ozark bass length-at-age deviated from the modeled growth curve at age 7 likely due to the few 7-and 8-year-old fish that were collected (Figure 5).

\subsection{Length-at-Age Comparison among Ambloplites Species}

Fish lengths from this study ranged from 61 (age 1) to $260 \mathrm{~mm}$ (age 9) for Ozark bass, while lengths used in the analysis among species ranged from 96 (age 2) to $275 \mathrm{~mm}$ (age 6) for shadow bass and 84 (age 2) to $259 \mathrm{~mm}$ (age 7) for rock bass. Although length generally increased with age across all species, an interaction was observed between age and Ambloplites species $(P<0.001$; Figure 6$)$. Shadow bass length-at-age was generally greater than or equal to that for Ozark bass, regardless of age, and greater than that for rock bass from ages 2 through 4 (Figure 6). After age 4, rock bass length-at-age surpassed that of the other the other two species. Growth rates of Ozark bass were initially greater up to age 3 compared to that for shadow bass (Figure 6). Rock bass growth rates were more similar to those for Ozark bass at ages 2 and 3, but were greater after age 3 (Figure 6). After age 3, the length-at-age relationship became more similar between Ozark bass and shadow bass (Figure 6).

\section{Discussion}

\subsection{Comparison of Ozark Bass Population Characteristics between Streams}

Several Ozark bass population characteristics differed somewhat between Crooked Creek and the Buffalo River. Catch-per-effort was substantially greater in Crooked Creek (101.5 fish/hour) than in the Buffalo River (32.9 fish/hour). Since CPE is sometimes related to fish density [27], there may have been a greater density (i.e., fish per linear river length) of Ozark bass in Crooked Creek 


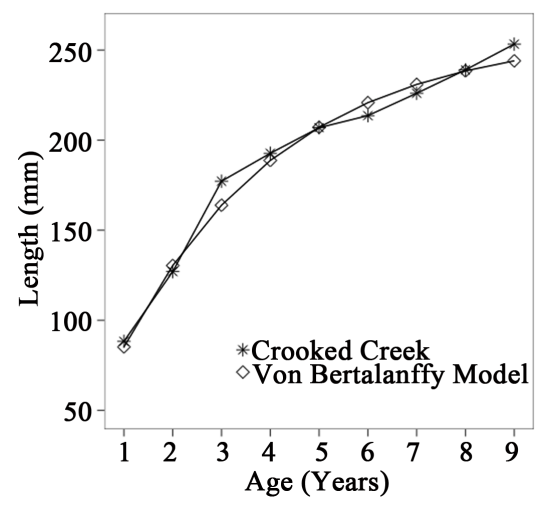

(a)

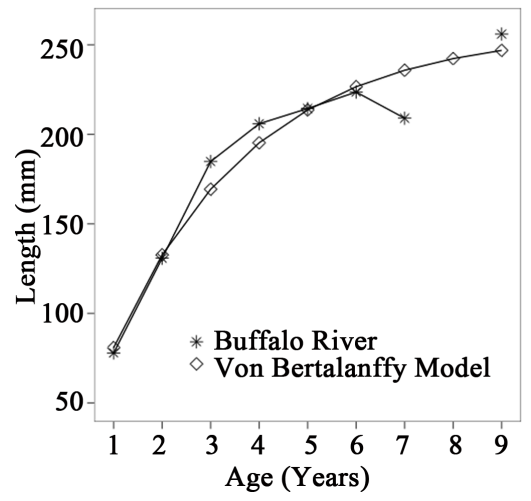

(b)

Figure 5. Ozark bass length-at-age estimated using the Von Bertalanffy equation compared to length-at-age of Ozark bass collected from a) Crooked Creek; and b) the Buffalo River. The estimated Von Bertalanffy growth curves are represented as diamonds, while asterisks represent measured length-at-age from Crooked Creek and Buffalo River.

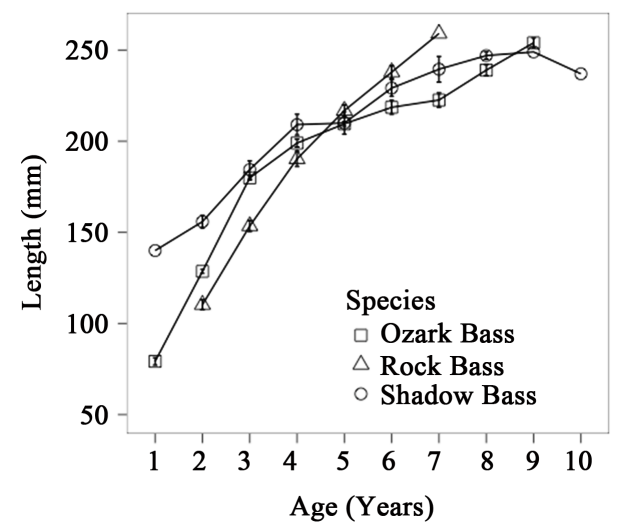

Figure 6. Ozark bass (squares), rock bass (triangles), and shadow bass (circles) length-at-age data. Shadow bass data were from the Eleven Point and Spring Rivers, Arkansas, from 2003 through 2007 [21]. Ozark bass data were from the Buffalo River and Crooked Creek, Arkansas, from summer 2013. Rock bass data were from the Osage Fork of the Gasconade River, Missouri, from fall 2011 (Craig Fuller, pers. comm.).

than in the Buffalo River or a greater number of fish recruited to the sampling gear was in the sampled sections of Crooked Creek at the time of sampling. With a three-fold greater drainage area, the Buffalo River watershed is larger than Crooked Creek's watershed [15], supporting the contention of greater fish density, thus resulting in greater capture success in Crooked Creek compared to the Buffalo River.

Crooked Creek is also nested within the Bull Shoals Lake Watershed [hydrologic unit code (HUC) 11010003], which has 26\% less forest and 16\% more agricultural land use than the Buffalo River Watershed (HUC 11010005) [28]. Increased nutrient loading in streams has been observed as percent agricultural land use increased [29]. Potentially greater concentrations of available nutrients in Crooked Creek, due to differences in land use within the watersheds, may have increased food availability to support a greater quantity of Ozark bass. 
However, the limited number of sampling locations and the local habitat may have affected CPE more than stream-scale characteristics (i.e., catchment size) or surrounding land use. McInerny and Cross [27] observed that largemouth bass (Micropterus salmoides) were more likely to avoid boat electroshocking equipment during the daytime compared to nighttime, leading to greater CPE during nighttime sampling. Furthermore, sample timing may also have affected the size structure of fish collected between samples (e.g., with smallmouth bass) [30]. However, if time of sampling (i.e., daytime vs. nighttime) had been the primary control on observed CPE differences between streams in this study, Buffalo River CPE would likely have been greater than that in Crooked Creek, since the Buffalo River was sampled at night. Differential sample times of the day between the two streams may have been a limitation of this study, but the data collected and results generated for an understudied fish species in the Ozark Highlands provides a reasonable starting point for future, more extensive research on the Ozark bass.

Similar to CPE, it was hypothesized that relative condition of Ozark bass would be similar between streams. However, relative condition was also greater in Crooked Creek $(P<0.001$; Figure 3). Greater relative condition has been linked to greater prey availability, better reproductive success, and increased growth [31]. This would suggest that food availability was greater in Crooked Creek than in the Buffalo River, which may also partially explain the greater CPE in Crooked Creek compared to the Buffalo River. Although exact fishing pressure on the streams remains unknown, differential fishing pressure is another possible explanation for observed differences in relative condition between streams, as anglers tend to keep the better-conditioned fish [32]. Even though both streams are popular fishing destinations, the Buffalo River receives more visitors and is better known because of its larger size and designation as a National Park Service unit [13] [14] and is more easily accessible by motorized boat from the White River, which is another popular fishing destination in the region.

Similar to CPE and relative condition, longer fish, in general, were collected from Crooked Creek than from the Buffalo River, with a $10 \mathrm{~mm}$ difference in mean total length between streams (Crooked Creek mean total length $=161.7$ $\mathrm{mm}$ and Buffalo River mean total length $=151.2 \mathrm{~mm}$ ). However, differences in fish length in each stream tended to increase as age increased, with greater mean length-at-age observed in Buffalo River fish after age 2 and up to age 6 (Figure 4). A relatively large number of 5-year-old fish were collected in Crooked Creek, indicating that was a strong year class, which may have contributed to the larger average size in Crooked Creek, compared to the Buffalo River. Observed length-at-age data were similar to the Von Bertalanffy growth model for Crooked Creek (Figure 5(a)). Buffalo River fish up to age 6 and at age 9 were comparable to the Von Bertalanffy growth models, but Buffalo River fish between age 6 and 9 were either not collected or shorter in length than predicted in the model, suggesting low abundance, potentially due to limited sample size 
and/or growth limitations (Figure 5(b)).

Whisenant and Maughan [17] observed 50\% of Ozark bass collected as part of their study along the Buffalo River were greater than $171 \mathrm{~mm}$ in length. Length results from this study were similar when data were combined across the Buffalo River and Crooked Creek, where $42 \%$ of Ozark bass collected from both streams had lengths that exceeded $171 \mathrm{~mm}$. More specifically, only 37\% of Ozark bass collected from the Buffalo River during this study were greater than $171 \mathrm{~mm}$, suggesting there were fewer relatively longer fish observed during this study than in 1989 [17]. However, 45\% of Ozark bass collected from Crooked Creek were greater than $171 \mathrm{~mm}$, supporting the observation that Ozark bass were generally longer in Crooked Creek than in the Buffalo River and were more similar to the results of Whisenant and Maughan's [17] study of Ozark bass in the Buffalo River.

In contrast to CPE, relative condition, and length, the hypothesis that annual survival would be lower in the Buffalo River was rejected after observing similarities in mean annual survival between the Buffalo River and Crooked Creek ( $50 \% \pm 7 \%$ and $55 \% \pm 5 \%$ for the $95 \% \mathrm{CI}$, respectively), where annual survival rates across all age classes did not differ between streams. Similar annual survival rates across all age classes may have been linked to the proportionality of fishing pressure and capture success relative to the size of each stream, since annual survival is directly related to total annual mortality, where total mortality is the sum of fishing mortality (e.g., anglers harvesting fish and fish death due to hooking) and natural mortality (e.g., predators, disease, and water quality issues) [33]. In contrast to some properties, it appears that there were also several Ozark bass population characteristics that were similar between the Buffalo River and Crooked Creek.

Mean annual survival of Ozark bass in the Buffalo River during this study ( $50 \% \pm 7 \%$ for the CI) was greater than the $42 \%$ (95\% CI not reported) mean annual survival reported by Whisenant and Maughan [17] for Buffalo River fish collected from the upper National Park Service boundary to near the Rush Access, which is approximately 22.5 river kilometers upstream from the current study's nearest sampling site. However, mean annual survival rates reported by Whisenant and Maughan [17] were calculated for Ozark bass age 5 to 8, while reported mean annual survival rates from this study were for fish age 2 to 9. Progressing from upstream to downstream, Whisenant and Maughan [17] reported decreasing annual survival rates for Ozark bass age 5 to 8 , with the lowest site-specific annual survival rate (33\%, CI not reported) reported at the farthest downstream sampling site near the Rush Access. Mean annual survival for fish age 5 to 8 collected from the Buffalo River in the present study was $26 \%( \pm 17 \%$ for the $95 \%$ CI). Though differences existed in collection location between the present and historical study, variations in reported survival suggest mean annual survival for fish in the 5- to 8-year-old category has potentially changed over time already, but uncertainty still remains because past mean annual survival records are unavailable for the LWA. It is also possible that there are longitudin- 
al trends in fish survival from up-river to down-river, but not enough data exist yet to sufficiently address this possibility.

\subsection{Comparison of Population Characteristics between Ozark Bass and Other Ambloplites Species}

Variability in growth rates and length-at-age were observed among Ambloplites species. With increasing age, length differences between Ozark bass and shadow bass became more similar, while differences between rock bass and Ozark bass length became more pronounced with age (Figure 6). Shadow bass mean annual survival in the Spring River and Eleven Point River in Arkansas was reported at $64 \%$ across all age groups [21], which was greater than the mean annual survival of Ozark bass across both streams in this study (52\%). Mean total lengths of Ozark bass collected in this study (151.2 and $161.7 \mathrm{~mm}$ for the Buffalo River and Crooked Creek, respectively) were smaller than shadow bass mean total length in Spring River [208.6 mm ( $\pm 0.99 \mathrm{SE})$ ], but more similar to shadow bass mean total length in Eleven Point River [161.9 ( \pm 1.64 SE)] [21]. Perhaps temporal and spatial factors influenced the differences in population characteristics for shadow bass collected from Spring River and Eleven Point River. In 2011, the mean total length of rock bass collected by the Missouri Department of Conservation from the Osage Fork of the Gasconade River in Missouri was 194.4 ( $\pm 0.9 \mathrm{SE}$ ). Mean length-at-age for rock bass from the Osage Fork ranged from $110.3 \mathrm{~mm}$ (age 2) to $259.1 \mathrm{~mm}$ (age 7), while combined mean length-at-age from Crooked Creek and Buffalo River ranged from $83.1 \mathrm{~mm}$ (age 1) to $254.7 \mathrm{~mm}$ (age 9). Thus, on average, Ozark bass in the present study were shorter than a single nearby rock bass populations in Missouri. Additionally, Whisenant and Maughan [17] reported rock bass grew faster than Ozark bass after age 1. However, some of the variability among Ozark, rock, and shadow bass length-age characteristics may be due to using otoliths (Ozark and shadow bass) compared to scales (rock bass) to determine fish ages.

\subsection{Potential Study Limitations}

This study represented observations of Ozark bass during a single year, from a single season, and collected by a single method. The resulting size structure of Ozark bass (Figure 2) determined in this study may not have been generated in an ideal manner and may be partially biased by collection method and fish behavior at that time of the year sampling was conducted [34]. A single year of data also limits assessment of inter-annual variations in size classes among the streams sampled due to environmental conditions (i.e., differential precipitation patterns), which may partially explain the apparent strong age 5 class in Crooked Creek. In addition, length-at-age data collected for this study compared similarly to the Von Bertalanffy estimated length-at-age model, except in the Buffalo River for age 7. The deviation from the model's prediction can be attributed to low sample size in the age 7 category, as only one age 7 Ozark bass was reported from Buffalo River during this study. However, results of this study still 
represent a useful starting point in the characterization this understudied fish species in streams of the Ozark Highlands-Boston Mountains ecoregions that can assist fisheries biologists and managers in understanding and protecting Ozark bass from developing water quality issues and other environmental changes.

Subsequent sampling events over multiple years would yield better understanding of temporal population shifts, reveal patterns in annual variation, and provide a better representation of the actual endemic Ozark bass population. With this information, future impacts to the Ozark bass, such as through land use or climate change, could be more easily recognized and management strategies assessed and implemented.

\section{Conclusion}

Establishing and monitoring population dynamics of endemic fish species allow for informed management decisions and better understanding about variations in fish populations. With little known about Ozark bass population dynamics, this study provided baseline information for establishing and improving current understanding about the Ozark bass and data for future determinations of natural and human-induced changes to the Ozark bass population in the Upper White River Basin. More specifically, results contributed to better understanding about variations in Ozark bass in Crooked Creek and the Buffalo River and comparisons to other Ambloplites species and will be useful to fisheries biologists and managers for setting and/or revising fish harvest regulations, such as length and catch limits or geographic restrictions to harvesting Ozark bass. Future studies that seek to understand fishing pressures on Ozark bass and collect additional population characteristic data over multiple years would be beneficial to the longevity of a healthy and thriving Ozark bass population.

\section{Acknowledgements}

The Arkansas Game and Fish Commission, specifically the District \#2 Fisheries Office, provided support, staff, and funding for this project. Shawn Hodges, Buffalo National River's Aquatic Ecologist, is gratefully acknowledged for his expertise, field assistance during the data collection process, and discussions. The National Park Service, specifically Buffalo National River, which graciously provided personnel, park access, and sampling equipment, is also gratefully acknowledged. Any use of trade, firm, or product names is for descriptive purposes only and does not imply endorsement by the U.S. Government.

\section{Conflicts of Interest}

The authors declare no conflicts of interest regarding the publication of this paper.

\section{References}

[1] Robison, H.W. and Buchanan, T.M. (1988) Fishes of Arkansas. University of Ar- 
kansas Press, Fayetteville.

[2] Cashner, R.C. and Suttkus, R.D. (1977) Ambloplites constellatus, a New Species of Rock Bass from the Ozark Upland of Arkansas and Missouri with a Review of Western Rock Bass Populations. American Midland Naturalist, 98, 147-161. https://doi.org/10.2307/2424721

[3] National Park Service (NPS) (2017) Surface-Water Quality in the Buffalo River (1985-2011).

http://buffaloriveralliance.org/resources/Pictures/Buffalo\%20National\%20River\%20 Water\%20Quality\%20Report\%201985\%20-\%202011\%20Final.pdf

[4] Ozarks Water Watch (OWW) (2018) Upper White River Basin Watershed. https://owwbeaverlake.org/beaver-lake/upper-white-river-basin-watershed

[5] Brown, A.V., Lyttle, M.M. and Brown, K.B. (1998) Impacts of Gravel Mining on Gravel Bed Streams. Transactions of the American Fisheries Society, 127, 979-994. https://doi.org/10.1577/1548-8659(1998)127<0979:IOGMOG>2.0.CO;2

[6] Arkansas Department of Environmental Quality (ADEQ) (2016) Final 2016 303(d) List Category 5 Streams.

https://www.adeq.state.ar.us/water/planning/integrated/303d/pdfs/2016/final-2016303d-list.pdf

[7] National Park Service (NPS) (2017) Visitor Use Statistics. https://irma.nps.gov/Stats/SSRSReports/Park\%20Specific\%20Reports/Annual\%20Pa rk\%20Recreation\%20Visitation\%20(1904\%20-\%20Last\%20Calendar\%20Year)?Park $=\mathrm{BUFF}$

[8] Arkansas Game \& Fish Commission (AGFC) (2018) Statewide Lengths and Daily Limits. https://www.agfc.com/en/fishing/daily-limits

[9] Environmental Protection Agency (EPA) (2016) Climate Impacts in the Southeast. https://19january2017snapshot.epa.gov/climate-impacts/climate-impactssoutheast_. html

[10] Middaugh, C.R., Kessinger, B. and Magoulick, D.D. (2016) Climate-Induced Seasonal Changes in Smallmouth Bass Growth Rate Potential at the Southern Range Extent. Ecology of Freshwater Fish, 27, 19-29. https://doi.org/10.1111/eff.12320

[11] National Park Service (NPS) (1983) Buffalo River-River Use Management Plan. U.S. Department of the Interior, National Park Service, Prepared by Buffalo River and Southwest Regional Office.

[12] Arkansas Geological Survey (2018) Select a Region. https://www.geology.arkansas.gov/geology/stratigraphy.html

[13] Panfil, M.S. and Jacobson, R.B. (2001) Relations among Geology, Physiography, Land Use, and Stream Habitat Conditions in the Buffalo and Current River Systems, Missouri and Arkansas. USGS/BRD/BSR-2001-0005. U.S. Department of the Interior, U.S. Geological Survey, Biological Resources Division, Columbia Environmental Research Center, Columbia.

[14] Daly, J.J., DeYoung, B., Hostetler, T. and Keller, R.J. (2002) Distribution of Clinostomum marginatum (Yellow Grub) Metacercaria in Smallmouth Bass Populations from Crooked Creek in North Central Arkansas. Journal of the Arkansas Academy of Science, 56, 42-46.

[15] United States Geological Survey (USGS) (2015) Streamstats Version 3.0. https://streamstats.usgs.gov/ss

[16] National Oceanic and Atmospheric Administration (NOAA) (2017) Data Tools: 1981-2010 Normals. National Centers for Environmental Information, Asheville. 
https://www.ncdc.noaa.gov/cdo-web/datatools/normals

[17] Whisenant, K.A. and Maughan, O.E. (1989) Smallmouth Bass and Ozark Bass in Buffalo River. Technical Report No. 28, U.S. Department of the Interior, U.S. National Park Service, Washington, D.C.

[18] Petersen, J.C. and Justus, B.G. (2005) The Fishes of Buffalo River, Arkansas 2001-2003. Scientific Investigations Report 2005-5130, U.S. Department of the Interior, U.S. Geological Society, Reston. https://doi.org/10.3133/sir20055130

[19] Robison, H.W., McAllister, C.T. and Shirley, K.E. (2011) The Fishes of Crooked Creek (White River Drainage) in Northcentral Arkansas, with New Records and a List of Species. Journal of the Arkansas Academy of Science, 65, 111-116.

[20] United States Geological Survey (USGS) (2013) National Water Information System: Mapper. https://maps.waterdata.usgs.gov/mapper/index.html

[21] Johnson, R.L., Henry, S.D. and Barkley, S.W. (2010) Distribution and Population Characteristics of Shadow Bass in Two Arkansas Ozark Streams. North American Journal of Fisheries Management, 30, 1522-1528.

https://doi.org/10.1577/M10-056.1

[22] Le Cren, E.D. (1951) The Length-Weight Relationship and Seasonal Cycle in Gonad Weight and Condition in the Perch (Perca fluviatilis). Journal of Animal Ecology, 20, 201-219. https://doi.org/10.2307/1540

[23] Quist, M.C., Pegg, M.A. and DeVries, D.R. (2012) Age and Growth. In: Zale, A.V., Parrish, D.L. and Sutton, T.M., Eds., Fisheries Techniques, 3rd Edition, American Fisheries Society, Bethesda, 677-731.

[24] Robson, D.S. and Chapman, D.G. (1961) Catch Curves and Mortality Rates. Transactions of the American Fisheries Society, 90, 181-189. https://doi.org/10.1577/1548-8659(1961)90[181:CCAMR]2.0.CO;2

[25] Beverton, R.J.H. and Holt, S.J. (1957) On the Dynamics of Exploited Fish Populations. Chapman and Hall, London.

[26] R Core Team (2015) R: A Language and Environment for Statistical Computing. R Foundation for Statistical Computing, Vienna. https://www.R-project.org

[27] McInerny, M.C. and Cross, T.K. (2000) Effects of Sampling Time, Intraspecific Density, and Environmental Variables on Electrofishing Catch per Effort of Largemouth Bass in Minnesota Lakes. North American Journal of Fisheries Management, 20, 328-336. https://doi.org/10.1577/1548-8675(2000)020<0328:EOSTID>2.3.CO;2

[28] Center for Advanced Spatial Technologies (CAST) (2006) Arkansas Watershed Information System: A Module of the Arkansas Automated Reporting and Mapping System. http://watersheds.cast.uark.edu/index.php

[29] Haggard, B.E., Moore, P.A. Jr. and Stanley, E.H. (2003) Nitrogen and Phosphorus Concentrations and Export from an Ozark Plateau Catchment in the United States. Biosystems Engineering, 86, 75-85. https://doi.org/10.1016/S1537-5110(03)00100-4

[30] Paragamian, V.L. (1989) A Comparison of Day and Night Electrofishing: Size Structure and Catch per Unit Effort for Smallmouth Bass. North American Journal of Fisheries Management, 9, 500-503. https://doi.org/10.1577/1548-8675(1989)009<0500:ACODAN>2.3.CO;2

[31] Blackwell, G.B., Brown, M.L. and Willis, D.W. (2000) Relative Weight (Wr) Status and Current Use in Fisheries Assessment and Management. Reviews in Fisheries Science, 8, 1-44. https://doi.org/10.1080/10641260091129161

[32] Shin, Y., Rochet, M., Jennings, S., Field, J.G. and Gislason, H. (2005) Using 
Size-Based Indicators to Evaluate the Ecosystem Effects of Fishing. ICES Journal of Marine Science, 62, 384-396. https://doi.org/10.1016/j.icesjms.2005.01.004

[33] Quinn II, T.J. and Deriso, R.B. (1999) Quantitative Fish Dynamics. Oxford University Press, Inc., New York.

[34] Neuman, R.M. and Allen, M.S. (2007) Size Structure. In: Guy, C.S. and Brown, M.L., Eds., Analysis and Interpretation of Freshwater Fisheries Data, American Fisheries Society, Bethesda, 375-422. 